Final peer reviewed manuscript accepted in European Competition Journal,

\begin{abstract}
This contribution considers whether a manufacturer of luxury goods, who operates a selective distribution system, may lawfully ban its appointed dealers from selling the contract goods via third-part online platforms under the EU competition rules. On the basis of an analysis of the relevant legal provisions and the existing case law, it is suggested that, while the aim of protecting a luxury image should in principle be considered a legitimate objective under Article 101 TFEU, a blanket ban that does not take into account the characteristics of the third-party platform should be deemed disproportionate. However, a ban on the use of third-party platforms should not be seen as a hardcore restriction within the meaning of Article 4 of Regulation (EU) no 330/2010, as long as the distributor has other viable options of selling the goods via the Internet.
\end{abstract}

\title{
Restrictions on the use of third-party platforms in selective distribution agreements for luxury goods
}

\author{
Anne C. Witt*
}

E-commerce is currently attracting a great deal of attention from antitrust circles. Over the past ten years, the Internet has significantly changed the way in which goods and services are distributed. Businesses are able to advertise and sell their goods to a wider range of consumers than was previously the case, and consumers benefit from being able to source goods from a broader range of distributors. By the same token, the Internet has created new opportunities for businesses to restrict competition to their advantage in ways not previously encountered by the enforcement agencies. This raises many novel questions for competition lawyers when trying to apply rules that were developed at a time when goods were sold in brick and mortar outlets, and the telefax was the ultimate means of telecommunication. The European Commission is currently

\footnotetext{
* Leicester Law School, University of Leicester. My thanks go to Giorgio Monti for his comments and suggestions on the draft. All mistakes are, of course, my own.
} 

2017.

Final peer reviewed manuscript accepted in European Competition Journal, carrying out a formal inquiry into the e-commerce sector with the aim of identifying common restrictions of competition in this sector and assessing whether the existing rules are capable of addressing these issues. ${ }^{1}$ The national competition authorities have been equally active, conducting their own market investigations ${ }^{2}$ and producing discussion papers on various e-commerce related questions. ${ }^{3}$

This article focuses on a specific question that has arisen in the distribution of luxury products: is it compatible with the EU competition rules for a manufacturer of luxury goods to operate a selective distribution network and to prohibit its appointed distributors from selling the contract goods on third-party online platforms such as ebay and Amazon? This is an issue of considerable practical relevance, and one on which opinions are currently deeply divided. In Groupement d'achat Edouard Leclerc, a judgment from 1996, the General Court ${ }^{4}$ had taken the view that it was legitimate and even in the interest of consumers for manufacturers of luxury products to use selective distribution systems in order to protect these goods' image and aura of exclusivity. ${ }^{5}$ However, in 2011, the case of Pierre Fabre shed doubt upon the validity of this principle. In a terse dictum, the Court held that a manufacturer's desire to protect a prestigious image could never justify a restriction of competition, and in particular not the use of selective distribution. ${ }^{6}$ Because this ruling did not engage with the previous case law, let alone clarify whether it had overruled Groupement d'achat Edouard Leclerc, the judgment created a fair degree of legal uncertainty. National courts and enforcement authorities have since adopted diverging positions on this point.

Moreover, in Pierre Fabre, the Court ruled in fairly broad terms that a contractual clause that prohibited the Internet as a method of marketing in a selective distribution agreement amounted to a hardcore restriction within the meaning of the former Block Exemption Regulation for Vertical Agreements. ${ }^{7}$ In the case of Pierre

\footnotetext{
${ }^{1}$ European Commission, Decision (HT.4607) of 6 May 2015 initiating an inquiry into the e-commerce sector pursuant to Article 17 of Council Regulation (EC) No 1/2003.

${ }^{2}$ E.g. Autorité de la concurrence, Avis $n^{\circ} 12-\mathrm{A}-20$ du 18 septembre 2012 relatif au fonctionnement concurrentiel du commerce électronique.

${ }^{3}$ Bundeskartellamt, Working Paper, ‘The Market Power of Platforms and Networks’ (15 June 2016), and

"Vertikale Beschränkungen in der Internetökonomie” (10 October 2013).

4 Then Court of First Instance.

${ }^{5}$ Case T-19/92 Groupement d'achat Edouard Leclerc v Commission ECLI:EU:T:1996:190.

${ }^{6}$ Case C-439/09 Pierre Fabre Dermo-Cosmétique v Président de l'Autorité de la concurrence and Ministre de l'Économie, de l'Industrie et de l'Emploi ('Pierre Fabre') ECLI:EU:C:2011:649, para 46.

${ }^{7}$ Supra, paras 51-59; European Commission, Regulation (EC) No 2790/1999 on the application of Article 81(3) of the Treaty to categories of vertical agreements and concerted practices [1999] OJ L336/21, Article 4(c).
} 

2017.

Final peer reviewed manuscript accepted in European Competition Journal,

Fabre, the manufacturer had imposed an absolute prohibition on online sales on his appointed distributors. The second question that has occupied and divided the national enforcement bodies ever since this ruling is therefore whether 'merely' prohibiting distributors from selling goods on a third-party platforms, while permitting the sale on the distributor's own website, should also be considered a hardcore restriction within the meaning of the current Block Exemption Regulation for Vertical Agreements. ${ }^{8}$

The aim of this contribution is to examine how restrictions on the use of thirdpart platforms in the context of selective distribution systems for luxury goods should be assessed under Article 101(1) TFEU and the current Block Exemption Regulation for Vertical Agreements. In particular, it aims to address whether the objective of protecting the image of a luxury good should, in principle at least, be capable of justifying the use of selective distribution. The second issue it examines is whether prohibiting distributors from selling luxury goods on third-party platforms should be considered a restriction of competition by object within the meaning of Article 101(1) TFEU. Finally, it analyses whether such a restriction should be considered a hardcore restriction within the meaning of the current Block Exemption Regulation for Vertical Agreements, Regulation (EU) No 330/2010.

To this end, the following analysis begins by briefly explaining the concept of a selective distribution system within the meaning of EU competition law, identifying the relevant legal provisions, and critically reviewing how the Court of Justice has applied these rules to selective distribution systems in the past. It further takes into account the diverging positions of several national competition agencies, national courts and the European Commission. On this basis, this contribution finally analyses the relevant legal issues and proposes an answer to the questions raised above.

\section{The concept of a selective distribution system}

Selective distribution systems, within the meaning of EU competition law, are arrangements in which the supplier choses to sell the contract good only to distributors who meet certain criteria, usually relating to their personal qualifications or their sales premises, and in which these distributors undertake not to sell on such goods to

\footnotetext{
${ }^{8}$ European Commission, Regulation (EU) No 330/2010 on the application of Article 101(3) of the Treaty on the Functioning of the European Union to categories of vertical agreements and concerted practices [2010] OJ L102/1.
} 

2017.

Final peer reviewed manuscript accepted in European Competition Journal, unauthorised distributors. ${ }^{9}$ Selective distribution has always been common practice for manufacturers of branded goods ion Europe, and the preliminary findings of the Commission's on-going E-commerce Sector Inquiry suggest that the advent of online distribution has only increased this trend. When asked to identify what measures they had taken in reaction to the growth of e-commerce over the last 10 years, $19 \%$ of manufacturers reported having introduced a selective distribution system where they had not applied selective distribution beforehand. 67\% of manufacturers reported that they had introduced new criteria in their distribution agreements. All in all, over half of the manufacturers who responded to the Commission's questionnaire replied that they nowadays made use of selective distribution for at least some of their products. ${ }^{10}$ When asked to identify their reasons for using selective distribution, manufacturers commonly stated that their purpose was to ensure high quality distribution, to influence the quality of pre- and after-sales services, to enhance the overall shopping experience of customers and to protect brand image. In particular with regard to the last aim, manufacturers specified that they used selective distribution to preserve consumer's prestige and luxury perceptions, as well as the reputation of their brand, by seeking to ensure an adequate sales environment. ${ }^{11}$

Producers of luxury goods have traditionally been particularly selective about the types of retailers whom they trust with selling their goods, and have commonly made admission to the distribution network dependent on the retail outlet meeting certain quality expectations on factors such as shop location, facade, name, decoration, fittings and the availability of other luxury brands, as well as the qualifications of sales staff. ${ }^{12}$ In the age of online retail, they have become keen to extend this control to their distributors' virtual distribution channels as well. They therefore often impose restrictions on online sales and set criteria for admission to their networks that de facto exclude certain types of Internet distributors, such as Ebay and Amazon. The latter, on the other hand, are very keen to gain access to luxury brands, and have long been lobbying the competition authorities to prohibit luxury manufacturers' selective

\footnotetext{
${ }^{9}$ Article 1(1)(e) of Commission Regulation (EU) No 330/2010 [2010] OJ L102/1.

${ }^{10}$ European Commission, Staff Working Document, Preliminary Report on the E-commerce Sector Inquiry SWD(2016) 312 final, paras 199 - 204 and 907-909.

${ }^{11}$ Supra, para 209.

${ }^{12}$ E.g. European Commission, Decision of 16 December 1991 (IV/33.242-Yves Saint Laurent Parfums) [1991] OJ L12/24, C.a. ; Decision of 24 July 1992 (IV / 33.542 - Parfums Givenchy) OJ [1992] L236/11, C.a.
} 
2017.

Final peer reviewed manuscript accepted in European Competition Journal, approach to distribution under the EU competition rules. ${ }^{13}$ As a first step, the following therefore explores the relevant legal rules and their interpretation in the case law.

\section{The relevant legal instruments and their interpretation in the case law}

Two legal instruments are key for the substantive assessment of selective distribution agreements under EU competition law: Article 101 TFEU and Regulation (EC) No 330/2010. ${ }^{14}$ Neither instrument is self-explanatory. Both contain a multitude of ambiguous terms that are open to interpretation by the enforcement bodies. Moreover, the combination of these two separate legal instruments makes for a relatively complex assessment that requires juggling a number of relatively rigid presumptions of legality and illegality. ${ }^{15}$

\section{Article 101 TFEU}

The key principles

Article 101 TFEU is one of the three main substantive antitrust provisions of EU law. Article 101(1) TFEU prohibits agreements that may affect trade between Member States and which have as their object or effect the prevention, restriction or distortion of competition within the internal market. The wording of this provision is relatively broad and does not spell out a clear test for assessing whether an agreement has the object or effect of restricting competition. It is the Court of Justice that has given the provision its current meaning. According to longstanding case law, restrictions by object are contractual restrictions that can be regarded, by their very nature, as being injurious to the proper functioning of normal competition. ${ }^{16}$ In other words, these are restrictions that are so obviously anticompetitive that it would amount to a waste of resources for the enforcement body to carry out a detailed assessment of their actual effects. Their anticompetitive nature is therefore presumed, ${ }^{17}$ although they can be saved by the exemption provided for in Article 101(3) TFEU. By contrast, contractual clauses that do not have the object of restricting competition need to be assessed more carefully as to their likely effects on competition.

${ }^{13}$ E.g. Ebay, Empowering Consumers by Promoting Access to the 21st century market - A Call for Action (2008), available at ec.europa.eu/competition/sectors/media/ebay_call_for_action.pdf; N Tait, 'Luxury goods makers battle online retailers' The Financial Times (19 February 2010).

${ }^{14}$ Commission Regulation (EU) No 330/2010, op. cit.

${ }^{15}$ For a critical analysis of the coherence and interaction of these two instruments, see Monti, "Restraints on Selective Distribution Agreements" (2003) 36 World Competition 489.

${ }^{16}$ Case C-8/08 T-Mobile Netherlands and Others ECLI:EU:C:2009:343, para 29.

17 Joined Cases 56 and 58/64 Établissements Consten and Grundig-Verkaufs-GmbH v Commission ECLI:EU:C:1966:41, p. 342. 
Final peer reviewed manuscript accepted in European Competition Journal, 2017.

While the European Commission has in recent years attempted to introduce a more uniform test for assessing agreements under Article 101(1) TFEU, which essentially enquires whether the agreement results in a lessening of competition, either because of coordination between competitors or anticompetitive foreclosure of rivals, ${ }^{18}$ the Court of Justice's approach has always been more specifically tailored to individual categories of agreements, in particular for vertical agreements. In the 1970s and 1980s, it thus created a number of specific tests for assessing different types of contractual clauses. ${ }^{19}$ The Court's test for assessing the legality of selective distribution agreements is one of the most complex and curious in this list. It was developed in the cases of Metro I and Metro II, which shall be discussed in the following. ${ }^{20}$

\section{The Metro cases}

Both Metro cases had at their origin a dispute between a German generalist cash-and-carry self-service wholesaler, Metro, and a manufacturer of high-end consumer electronics, SABA. SABA operated a policy of only distributing its goods through specialist wholesalers. Having failed to be admitted to SABA's distribution network, Metro brought an action for annulment against the European Commission's decision approving SABA's model distribution contract. It argued that the system eliminated competition from non-specialist distributors, who, by cutting services typically provided by specialist traders, would have been able to offer SABA goods at lower prices than specialist dealers. Consequently, SABA distribution system resulted in higher prices for consumers, which Metro considered incompatible with the purpose of Article 101(1) TFEU. ${ }^{21}$ SABA argued that it chose to distribute its goods through specialist dealers because this ensured that buyers received expert technical advice and support for these goods.

The Court of Justice agreed with Metro insofar as it accepted that price competition was 'not generally emphasised' in selective distribution systems, ${ }^{22}$ i.e. that it was likely to result in higher prices. However, it also held that, while price

\footnotetext{
${ }^{18}$ European Commission, Guidelines on the application of Article 81(3) of the Treaty [2004] OJ C101/97, paras 24-27. For a more detailed discussion of this development, see Witt, The More Economic Approach to EU Antitrust Law (Hart Publishing, 2016), Chapter 7.

${ }^{19}$ For franchising agreements, for example, see Case 161/84 Pronuptia de Paris ECLI:EU:C:1986:41, para 27; for single banding agreements, see Case C-234/89 Stergios Delimitis v Henninger Bräu ECLI:EU:C:1991:91.

${ }^{20}$ Case 26/76 Metro SB-Großmärkte v Commission ('Metro I') ECLI:EU:C:1977:167; Case 75/84 Metro SB-Großmärkte v Commission ('Metro II') ECLI:EU:C:1986:399.

${ }^{21}$ Then Article 85(1) EEC.

${ }^{22}$ Case 26/76 Metro I, op. cit., para 21.
} 

2017.

Final peer reviewed manuscript accepted in European Competition Journal, competition was so important that it could never be eliminated, it did not constitute the only effective form of competition or one to which absolute priority had to be accorded in every case. The exemption provision of Article 101(3) TFEU showed that the aim of maintaining workable competition could be reconciled with other legitimate objectives. Certain restrictions on competition were therefore permissible, provided that they were essential for attaining those other objectives and did not eliminate competition entirely. Maintaining a certain price level for specialist retailers and wholesalers that ensured the continued existence of this channel of distribution in the interest of consumers was such a legitimate objective. ${ }^{23}$ On the basis of these considerations, the Court ruled that selective distribution agreements constituted an aspect of competition that was compatible with Article 101(1) TFEU if they fulfilled three cumulative conditions: (i) the characteristics of the product in question necessitated such a network in order to preserve its quality or to ensure its proper use, (ii) resellers were chosen on the basis of objective criteria of a qualitative nature relating to the technical qualifications of the reseller and his staff and the suitability of his trading premises, laid down uniformly for all potential resellers and not applied in a discriminatory fashion, (iii) the selection criteria did not go beyond what was necessary. ${ }^{24}$ In the case of Metro II, it added a fourth condition: the number of similar distribution systems in the market must not preclude the possibility of other forms of distribution or result in a rigid price structure. $^{25}$

This test, which the Court stands by to this day, is somewhat of an oddity these days. First, it balances specific pro-competitive effects against the system's anticompetitive effects under Article 101(1) TFEU already, rather than take them into account under Article 101(3) TFEU as it does in the context of most, although by no means all, types of agreements. Second, it is remarkably out of sync with the more economic approach that the European Commission introduced in the early 2000s.

Selective distribution agreements are vertical agreements, which, according to current mainstream economics, have great potential for generating pro-competitive effects and are generally less likely to generate serious anticompetitive effects than horizontal agreements. Industrial organisation theory thus takes the view that the main

\footnotetext{
23 Ibid.

${ }^{24}$ Ibid, para 20.

${ }^{25}$ Case 75/84 Metro II, op. cit., para 40.
} 

2017.

Final peer reviewed manuscript accepted in European Competition Journal, dangers emanating from vertical agreements are the foreclosure of competitors (which is only deemed problematic if this results in consumer harm), coordinated effects (if the agreement were to facilitate collusion either at the manufacturer or retailer level), and a softening of competition that lowers undertakings' incentives to compete aggressively. ${ }^{26}$ On the other hand, vertical restraints are also deemed capable of generating significant welfare-enhancing effects. It is well known that selective distribution systems, in particular, are considered an effective contractual means of improving the quality of pre-sales services and promotional efforts by eliminating a free-rider problem between distributors. ${ }^{27}$ Consequently, most economists take the view that vertical agreements should never be presumed illegal under an object rule, but assessed as to their actual or likely anticompetitive effects, which are then to be balanced against their pro-competitive effects. ${ }^{28}$

The European Commission has largely embraced these principles over the past fifteen years. Its guidelines on vertical restraints are based on the premise that vertical agreements have a great potential for pro-competitive effects and, because they merely restrict intra-brand competition, are not likely to result in serious harm to competition as long as there is healthy inter-brand competition. The Commission is therefore also generally in favour of assessing vertical agreements as to their actual effects on competition and consumer welfare in each individual case. ${ }^{29}$ Incidentally, this has been the approach of US antitrust law since the late 1970s, when the Chicago School convinced the US Supreme Court of the validity of these economic arguments. One by one, the US Supreme Court reversed its rules of per se illegality for vertical agreements under sec. 1 of the Sherman Act, and ruled that they were to be assessed under a rule of reason as to their actual effects instead. ${ }^{30}$ Since Leegin, this is now even the case for minimum resale prices imposed by the manufacturer, ${ }^{31}$ a practice that is still considered

\footnotetext{
${ }^{26}$ E.g. Lafontaine and Slade, "Exclusive Contracts and Vertical Restraints" in Buccirossi, Handbook of Antitrust Economics (Cambridge MA, MIT Press, 2008) 391-414.

${ }^{27}$ E.g. Vincent Verouden, "Vertical Agreements: Motivation and Impact”, in 3 Issues in Competition Law and Policy 1813, 1821 (ABA Section of Antitrust Law 2008).

${ }^{28}$ Paolo Buccirossi, "Vertical restraints on e-commerce and selective distribution" (2015) 11 J.C.L. \& E. 747.

${ }^{29}$ European Commission, Guidelines on Vertical Restraints [2010] OJ C130/1, paras 96-121.

${ }^{30}$ E.g. Continental T. V., Inc v GTE Sylvania Inc, 433 U.S. 36 (1977); State Oil Co v Khan, 522 U.S. 3 (1997); Northwest Wholesale Stationers, Inc v Pacific Stationery \& Printing Co, 472 U.S. 284, 298 (1985); FTC v Indiana Federation of Dentists, 476 U.S. 447 (1986).

${ }^{31}$ Leegin Creative Leather Products, Inc v PSKS, Inc, 127 S.Ct. 2705 (2007).
} 

2017.

Final peer reviewed manuscript accepted in European Competition Journal, to be restrictive by object by the European Court of Justice. ${ }^{32}$ Selective distribution agreements, as they are known in Europe, are therefore treated no differently than any other vertical agreement under US antitrust law. In fact, there does not even appear to exist a special term, let alone test, for this type of contract in the US case law.

In comparison, the European Court of Justice’s Metro test for assessing selective distribution agreements is very different. It relies heavily on legal presumptions of legality and illegality. If the product requires selective distribution to protect its quality or to ensure its proper use, the agreement is deemed compatible with Article 101(1) TFEU if retailers are selected on the basis of qualitative and objective criteria that are applied in a non-discriminatory manner and do not go beyond what is necessary to achieve the aim of safeguarding the product's quality or ensuring its proper use. If the selection criteria are quantitative in nature, ${ }^{33}$ are disproportionate or are applied in a discriminatory manner, the contract is deemed to restrict competition within the meaning of Article 101(1) TFEU. ${ }^{34}$ Unsurprisingly, the Metro test is commonly criticised by economists as being too formalistic and unable to capture the likely effects on competition in a reliable manner. ${ }^{35}$ It has, of course, the advantage of being easier to apply for lawyers than a test that requires a detailed analysis of a specific distribution agreement's pro- and anticompetitive effects and then balancing these often very diverse effects against each other in order to determine the overall competitive nature of the agreement.

Throughout the 1980s and 1990s, the European Commission applied the Metro test to selective distribution systems operated by the manufacturers of very diverse types of goods, ranging from consumer electronics, ${ }^{36}$ to personal computers, ${ }^{37}$

\footnotetext{
${ }^{32}$ E.g. Case 243/83 Binon v Agence et messageries de la presse ECLI:EU:C:1985:284, para 44.

${ }^{33}$ For example, because the manufacturer put a ceiling on the number of distributors he intends to admit to the network.

${ }^{34}$ It can, of course, still be exempted under Article 101(3), either individually or by means of a Block Exemption Regulation.

${ }^{35}$ E.g. Buccirossi, "Vertical restraints on e-commerce and selective distribution” (2015) 11(3) J.C.L. \& E. 747; Specifically in the context of luxury goods, see: Buettner, Coscelli, Vergé and Winter, "An Economic Analysis of the Use of Selective Distribution by Luxury Goods Suppliers” (2009) 5 ECJ 201. For a highly critical discussion of the latter, see Kinsella, Melin and Schropp, "Comments on the CRA Paper Entitled 'An Economic Analysis of the Use of Selective Distribution by Luxury Goods Suppliers" (2009) 5 ECJ 227, and the riposte: Buettner, Coscelli, Vergé \& Winter, "Selective Distribution by Luxury Goods Suppliers: A Response to Kinsella Et Al”, (2009) 5 ECJ 613.

${ }^{36}$ E.g. European Commission, Decision of 10 July (Case IV/29.420 - Grundig' s EEC distribution system) [1985] OJ L233/1.

${ }^{37}$ European Commission, Commission Decision of 18 April 1984 (Case IV/30.849 - IBM personal computer) [1984] OJ L118/24.
} 

2017.

Final peer reviewed manuscript accepted in European Competition Journal, photographic equipment, ${ }^{38}$ but also high quality ceramics ${ }^{39}$ and jewellery, ${ }^{40}$ amongst many others. Consequently, the General Court regularly had the opportunity to review the application of this case law and further develop its principles. Of these judgments, one is of particular importance for the issues under discussion in this contribution, and shall be briefly discussed in the following.

\section{Groupement d'achat Edouard Leclerc}

In the two Metro cases, the Court of Justice had been willing to condone the restriction of competition inherent in selective distribution systems for 'high quality and technically advanced consumer durables ${ }^{41}$ on the grounds that such products required expert technical pre-sales advice. ${ }^{42}$ In 1980, it indicated that the Metro formula could also apply to newspapers because of their extremely short shelf lives, which necessitated choosing distributors particularly carefully. ${ }^{43}$ In the mid-1990s, the General Court further extended this case law to luxury goods.

In two separate proceedings, the Groupement d'achat Edouard Leclerc ('Galec'), a purchasing association which supplied a network of French supermarkets, brought actions for annulment against two Commission decisions exempting the distribution systems of two producers of luxury cosmetic product, Parfums Givenchy ('Givenchy') ${ }^{44}$ and Yves Saint Laurent Parfums ('Yves Saint Laurent'). ${ }^{45}$ Both Givenchy and Yves Saint Laurent operated selective distribution systems and made the admission to this system dependent on a number of conditions, relating in particular to the professional qualifications of staff, location and fittings of the retail outlet, cooperation on advertising and promotion, and the availability in the retail outlet of a sufficient number of competing brands to reflect the image of the products in question. Distributors were required, for example, to employ staff with a professional qualification in perfumery, to provide consulting and demonstration services, and the location and fittings of the retail outlet had to reflect the prestige of the brand name. Galec had repeatedly tried and

\footnotetext{
${ }^{38}$ European Commission, Decision of 2 December 1981 (Case IV/25.757 - Hasselblad) [1982] OJ L161/18.

${ }^{39}$ European Commission, Decision of 16 December 1985 (Case IV/30.665 - Villeroy \& Boch) [1985] OJ L376/15.

${ }^{40}$ European Commission, Decision of 5 December 1983 (Case IV/30.668 - Murat) [1983] OJ L348/20.

${ }^{41}$ Case 26/76 Metro I, op. cit., para 20.

42 Case 75/84 Metro II, op. cit, para 54.

${ }^{43}$ Case 126/80 Maria Salonia v Giorgio Poidomani et al ECLI:EU:C:1981:136, paras 24-26; Case 243/83

Binon v Agence et messageries de la presse ECLI:EU:C:1985:284, para 32.

${ }^{44}$ Case T-19/92 Groupement d'achat Edouard Leclerc v Commission ECLI:EU:T:1996:190.

${ }^{45}$ Case T-88/92 Groupement d'achat Edouard Leclerc v Commission ECLI:EU:T:1996:192.
} 

2017.

Final peer reviewed manuscript accepted in European Competition Journal, failed to gain access to these networks, as the supermarkets it supplied did not meet the selection criteria. The Commission assessed these distribution systems under the Metro test, and found that a number of the contractual obligations passed the test, whereas the remainder could be exempted under Article 101(3) TFEU because they were necessary to preserve the luxury image of the brands in question. ${ }^{46}$

The General Court confirmed the Commission's analysis on most points. In particular, it held that while the Metro test was originally developed for high-quality and technically advanced consumer durables, other types of products could also require selective distribution. It considered that this was the case of luxury cosmetics and perfumes. In addition to being the result of meticulous research and using materials of high quality, these products enjoyed a 'luxury image' in the eyes of consumers, which distinguished them from similar products. Accordingly, the characteristics of luxury cosmetics could not be limited to their material characteristics but also encompassed the specific perception that consumers had of them. ${ }^{47}$ It was in the interests of consumers seeking to purchase luxury cosmetics that their 'aura of luxury' was not tarnished, as they would otherwise no longer be regarded as luxury products. Generalised distribution of such products, as a result of which the manufacturer would have no opportunity of ensuring that they were sold in appropriate conditions, would entail the risk of deterioration in product presentation, which could harm the luxury image and thus the very character of the products. ${ }^{48}$ Criteria that sought to ensure that such goods were presented in an a manner that preserved their luxury image therefore pursued an objective which improved competition by preserving the luxury image in the interests of consumers, and thus counterbalanced the restriction of competition inherent in the selective distribution system. The General Court therefore concluded that such criteria constituted a legitimate requirement for the purposes of the case law established in Metro. $^{49}$

\footnotetext{
${ }^{46}$ European Commission, Decision of 16 December 1991 (Case IV/33.242 - Yves Saint Laurent Parfums) [1992] OJ L12/24, and European Commission, Decision of 24 July 1992 (Case IV/33.542 - Parfums Givenchy system of selective distribution) [1992] OJ L236/11.

${ }^{47}$ Case T-19/92 Groupement d'achat Edouard Leclerc, op. cit, paras 112 to 123.

${ }^{48}$ Ibid, para 121.

${ }^{49}$ Ibid, paras 118-123; likewise: Case T-88/92 Groupement d'achat Edouard Leclerc, op. cit., paras 106117.
} 
Final peer reviewed manuscript accepted in European Competition Journal, 2017.

\section{Pierre Fabre}

The last piece of the puzzle is the case of Pierre Fabre from $2011 .^{50}$ Pierre Fabre Dermo-Cosmétique ('Pierre Fabre') was a French manufacturer of non-medicinal cosmetics and personal care products, which it distributed through a selective distribution system. It sought to market its cosmetics primarily though retail pharmacies. To this end, its standard distribution contract stipulated that sales had to be made exclusively in a physical space, in which a qualified pharmacist had to be present. ${ }^{51}$ The French competition authority interpreted this clause as prohibiting Pierre Fabre retailers from selling the contract goods online, and declared the distribution system incompatible with Article 101 TFEU and the equivalent French competition rule. ${ }^{52}$ On appeal, the French Court decided to stay the proceedings and ask the European Court of Justice for guidance on a number of legal questions. In particular, it enquired whether an absolute ban on selling contract goods to end-users via the Internet, imposed on authorised distributors in the context of a selective distribution network, constituted a restriction of competition by object for the purposes of Article 101(1) TFEU. ${ }^{53}$ It also asked for clarification on the interpretation of the Block Exemption Regulation for Vertical Agreements. ${ }^{54}$ This part of the judgment is discussed under the next heading.

The Court of Justice began its analysis by stating that selective distribution agreements restricted competition by object within the meaning of Article 101(1) TFEU unless they fulfilled the Metro conditions. ${ }^{55}$ Second, it held that selective distribution systems that aimed at the attainment of a legitimate goal capable of improving competition in relation to factors other than price, were compatible with Article 101(1) TFEU, in so far as resellers were chosen on the basis of objective criteria of a qualitative nature, laid down uniformly for all potential resellers and not applied in a discriminatory fashion, that the characteristics of the product in question necessitated

\footnotetext{
${ }^{50}$ Case C-439/09 Pierre Fabre, op. cit.

${ }^{51}$ Pierre Fabre presumably chose this somewhat complicated construction because requiring that the distributor be a retail pharmacy outright was deemed a quantitative and therefore unlawful selection criterion in Case T-19/91 Société d'Hygiène Dermatologique de Vichy ECLI:EU:T:1992:28, paras 65-68.

52 Autorité de la concurrence, Décision nº 08-D-25 du 29 octobre 2008 relative à des pratiques mises en œuvre dans le secteur de la distribution de produits cosmétiques et d’hygiène corporelle vendus sur conseils pharmaceutiques, available at http://www.autoritedelaconcurrence.fr/pdf/avis/08d25.pdf.

${ }^{53}$ Case C-439/09 Pierre Fabre, op. cit., para 31.

54 Then Commission Regulation (EC) No 2790/1999 on the application of Article 81(3) of the Treaty to categories of vertical agreements and concerted practices [1999] OJ L336/21.

${ }^{55}$ Ibid, para 39.
} 
2017.

Final peer reviewed manuscript accepted in European Competition Journal,

such a network in order to preserve its quality and ensure its proper use and, finally, that the criteria laid down did not go beyond what was necessary. ${ }^{56}$

On this premise, the Court turned to the question whether a contractual clause such as that underlying the main proceedings could be held to pursue a legitimate objective. While emphasising that it was for the national court to determine what objective Pierre Fabre actually pursued, it was the Court of Justice's role to provide guidance on what could be considered a legitimate goal under Article 101(1) TFEU. ${ }^{57}$ It first pointed out that, under the Treaty's free movement rules, the Court did not accept arguments relating to the need to provide individual advice to the customer and to ensure their protection against the incorrect use of products in the context of nonprescription medicines and contact lenses as justifying a ban on Internet sales. ${ }^{58}$ It then briefly turned to Pierre Fabre's argument that it had employed this particular type of distribution system in order to maintain the prestigious image of Pierre Fabre products. In one sentence, and without any further rationalisation, the Court ruled that the aim of maintaining a prestigious image was not a legitimate aim for restricting competition and could therefore not justify a finding that a contractual clause pursuing such an aim did not fall within Article 101(1) TFEU. ${ }^{59}$ On this basis, the Paris Court of Appeal later upheld the French Competition Authority's prohibition decision. ${ }^{60}$

\section{Questions raised by the judgment in Pierre Fabre}

While the Court's judgment in Pierre Fabre clarifies a number of points, it also raises many new questions. First, the judgment makes clear that the Court considers selective distribution arrangements to restrict competition by object unless they fulfil the four conditions set out in Metro I and II. This had not been entirely obvious from the previous case law. The Metro formula is relatively elaborate for a test that determines whether an agreement is so obviously dangerous for competition that it would unreasonable to assess its effects. After all, it requires the enforcement body to determine whether (i) the characteristics of the product in question necessitate such a network in order to preserve its quality and ensure its proper use, (ii) resellers are

56 Ibid, paras 40, 41, citing Cases 26/76 Metro I, op. cit., para 20, and 31/80 L'Oréal ECLI:EU:C:1980:289, paras 15 and 16.

${ }^{57}$ Case C-439/09 Pierre Fabre, op. cit., para 42.

${ }^{58}$ Ibid, para 44, citing Deutscher Apothekerverband ECLI:EU:C:2003:664, paras 106, 107 and 112, and Case C-108/09 Ker-Optika ECLI:EU:C:2010:725, para 76.

${ }^{59}$ Case C-439/09 Pierre Fabre, op. cit., paras 45 and 46.

${ }^{60}$ Cour d'appel de Paris, judgment of 31 January 2013 (n²008/23812). 

2017.

Final peer reviewed manuscript accepted in European Competition Journal, chosen on the basis of objective criteria of a qualitative nature, laid down uniformly for all potential resellers and not applied in a discriminatory fashion, (iii) that the criteria laid down do not go beyond what is necessary, and (iv) that the cumulative effect of such agreements do not result in foreclosing other types of distributors or result in a rigid price structure. This could just as well have been understood as a highly formalistic test for assessing the effects of a selective distribution agreement.

Second, the ruling appears to add a fifth condition to the existing Metro test: the manufacturer must be pursuing a legitimate goal capable of improving competition in relation to factors other than price by means of its selective distribution system. Alternatively, this requirement may always have been implied in the first condition of the old Metro test, which required that the characteristics of the product in question necessitated such a network in order to preserve its quality or to ensure its proper use, in which case one could conclude that the Court used to consider preserving a product's quality or ensuring its proper use legitimate requirements.

However, in Pierre Fabre, the Court was not swayed by the undertaking's argument that it required retailers to sell the goods in a physical space and in the presence of a qualified pharmacist in order to afford customers' qualified pre-sales advice. Pierre Fabre had argued that it had wished to ensure that consumers received the best possible advice when buying its products, and that in order to give the best possible advice a pharmacist had to observe the skin, hair and scalp of the client in person. ${ }^{61}$ The Court responded to this argument by stating that its case law on the free movement rules made clear that it did not accept arguments relating to the need to provide individual advice to the customer and to ensure his protection against the incorrect use of products in the context of non-prescription medicines as justifying a ban on Internet sales. It is not clear from this whether the Court no longer considers ensuring a product's proper use a legitimate aim as it had done in the Metro cases, or whether it merely considered specialist advice for unnecessary for cosmetic products. Even if the Court merely meant to say the latter, one might also have to reconsider the previous case law on consumer electronics on the basis of Pierre Fabre. Is specialist advice really necessary to ensure the proper use of a television set or radio these days, if it is deemed unnecessary for contact lenses and expensive skin care products?

${ }^{61}$ Opinion of Mr Advocate General Mazák in Case C-439/09 Pierre Fabre ECLI:EU:C:2011:113, para 19. 
Final peer reviewed manuscript accepted in European Competition Journal, 2017.

Even more puzzling is the unequivocal statement in Pierre Fabre that the aim of maintaining a prestigious image is not a legitimate purpose for restricting competition. ${ }^{62}$ The Court does not provide any reasoning for this conclusion. Neither does it explain how it is compatible with its ruling in Edouard Leclerc, in which the General Court had explicitly held that the 'luxury image' and 'aura of exclusivity' were part of the main characteristics of luxury products. Not only had the General Court considered this image worth protecting in the interest of consumers. It had deemed it capable of justifying selective distribution, because generalised distribution of such products would risk harming the 'luxury image' and thus the very character of the products. ${ }^{63}$ It is curious that the judgment in Pierre Fabre does not even mention this case. The Advocate General's Opinion in Pierre Fabre, incidentally, had drawn on this precedent, and recommended that the Court adhere to its general principles. ${ }^{64}$

The Court's dictum in Pierre Fabre that the goal of maintaining a prestigious image is not a legitimate aim for restricting competition has since led to a great deal of uncertainty as to whether the principles established in Edouard Leclerc remain valid. The German competition authority, ${ }^{65}$ for example, seems to have interpreted Pierre Fabre as meaning that the protection of a product's image, even in the case of a luxury image, can no longer justify selective distribution systems. ${ }^{66}$ By contrast, a number of German courts consider that Edouard Leclerc was not overruled and that the aim of protecting the image of a high quality product of a reputable brand may very well justify prohibiting retailers from selling the manufacturer's goods on third-party auction platforms such as ebay, as long as the conditions of the Metro test are fulfilled. ${ }^{67}$ In France, the question is equally disputed. In January 2014, the Commercial Court of Paris deemed Coty France's selective distribution system, which prohibited online sales of luxury cosmetics, compatible with Article 101(1) TFEU on the basis of Metro. ${ }^{68}$ On appeal, the Cour d'appel de Paris disagreed and held the prohibition of online sales incompatible with Article 101(1) TFEU. ${ }^{69}$ Likewise, in 2012, the French Competition

\footnotetext{
62 Case C-439/09 Pierre Fabre, op. cit., para 46.

63 ibid, para 121.

${ }^{64}$ Opinion of Mr Advocate General Mazák in Case C-439/09 Pierre Fabre, op. cit., paras 44-57.

65 Bundeskartellamt.

${ }^{66}$ Bundeskartellamt, Decision of 26 August 2015 - B2-98/11 - Asics, para 262.

${ }^{67}$ OLG Frankfurt, Judgment of 22 December 2015 - Az 11 U 84/14 (Kart), reversing on this point the judgment of the previous instance court (LG Frankfurt/Main, Judgment of 18 June 2014 - AZ. 2-03 O 158/13); KG Berlin, Judgment of 29 September 2013, Az. 2 U 8/09 (Kart).

68 Tribunal de Commerce de Paris, Judgment of 23 January 2014, RG n 11/000500.

${ }^{69}$ Cour d'appel de Paris, Judgment of 25 May 2016, RG n 14/03918.
} 

2017.

Final peer reviewed manuscript accepted in European Competition Journal,

Authority found the selective distribution system of a manufacturer of high quality Hi-fi and home cinema equipment in which the manufacturers prohibited their distributors from marketing these products online incompatible with Article 101(1) TFEU, citing, amongst others, the Court of Justice's ruling in Pierre Fabre that the protection of a prestigious brand name could not justify a restriction of competition. ${ }^{70}$

Given this situation, it is crucial for the uniformity of EU law that the Court of Justice clarify its position on this point. The case of Coty Germany, ${ }^{71}$ which is currently pending, and in which a German Court asked the Court of Justice for interpretative guidance on the assessment of selective distribution agreements for luxury goods under the EU competition rules, would be the perfect opportunity to do so. In particular, the Court needs to clarify whether its ruling in Pierre Fabre really is to be interpreted as meaning that the protection of a product's name and image is entirely irrelevant in a competitive assessment under Article 101 TFEU. Before offering a number of suggestions on this issue, the following will briefly explain the second relevant legal basis, Regulation (EU) no 330/2010, and the relevant legal questions.

\section{The Block Exemption Regulation on Vertical Restraints}

The legal provision

Article 101(3) TFEU provides that the prohibition of Article 101(1) TFEU does not apply if the restrictive agreement also engenders certain desirable effects that outweigh its anticompetitive effects. In order to benefit from this exemption, the agreement must (i) contribute to improving the production or distribution of goods or to promoting technical or economic progress, (ii) allow consumers a fair share of the resulting benefit, (iii) not impose on the undertakings concerned restrictions which are not indispensable to the attainment of these objectives, and (iv) not afford them the possibility of eliminating competition in respect of a substantial part of the products in question. Much like the wording of Article 101(1) TFEU, these conditions are broad and in need of interpretation. It is not immediately obvious to the non-initiated reader, for example, what is meant by 'contribution to the production of goods or services' or how to determine whether the share passed on to consumers is fair. An individual

\footnotetext{
${ }^{70}$ Autorité de la Concurrence, Decision n ${ }^{\circ} 12-\mathrm{D}-23$ of 12 December 2012 relative à des pratiques mises en œuvre par la société Bang \& Olufsen dans le secteur de la distribution sélective de matériels hi-fi et home cinéma, para 53.

${ }^{71}$ Request for a preliminary ruling from the Oberlandesgericht Frankfurt am Main (Germany) lodged on 25 April 2016 - Coty Germany GmbH v Parfümerie Akzente GmbH (Case C-230/16) [2016] OJ C260/21.
} 

2017.

Final peer reviewed manuscript accepted in European Competition Journal, assessment under Article 101(3) TFEU therefore requires a solid knowledge of the case law interpreting this provision. It also confers a certain degree of discretion on the enforcement authority by requiring them to decide whether the restriction is indispensible to the attainment of the beneficial effect. This makes the outcome of an assessment under Article 101(3) TFEU difficult to predict even for experts.

In order to make the application of Article 101(3) TFEU easier for undertaking, as well as the administrative enforcement authorities and national courts, the Council has enabled the Commission to confer the effect of Article 101(3) TFEU en bloc on certain categories of agreements in so-called Block Exemption Regulations. The aim was for Block Exemption Regulations to be formulated in a more straightforward manner than Article 101(3) TFEU and to ensure that the legal assessment they prescribed would be easier and more predictable than an individual assessment under Article 101(3) TFEU. This was to be achieved by incorporating simple rules of thumb.

Currently, the relevant Block Exemption Regulation for the assessment of selective distribution agreements is Commission Regulation 330/2010, the so-called general Block Exemption Regulation for Vertical Agreements. ${ }^{72}$ Article 2 of the Regulation generally exempts all vertical agreements from the application of Article 101(1) TFEU. However, this exemption is subject to the conditions and exceptions spelled out in the remainder of the Regulation, of which Articles 3 to 5 contain the most important. Article 3 stipulates that the Block Exemption does not apply to agreements between undertakings that exceed a certain market share threshold, the presumption being that the higher the market share, the more likely the parties are to have market power and to be capable of inflicting serious harm on consumers. ${ }^{73}$ Further, Article 4 of Regulation 330/2010 lists a number of so-called hardcore restrictions, which are considered particularly dangerous to competition and therefore unlikely to meet the conditions of Article 101(3) TFEU in practice. If an agreement contains one of these hardcore restrictions, this has the effect of removing the entirety of the agreement from the scope of the Block Exemption Regulation. It is then necessary to revert to an individual assessment under Article 101(3) TFEU directly. Article 5 of Regulation

\footnotetext{
${ }^{72}$ Commission Regulation (EU) No 330/2010, op. cit.

73 According to Article 3(1) of Commission Regulation (EU) No 330/2010, the exemption provided for in Article 2 shall apply on condition that the market share held by the supplier does not exceed $30 \%$ of the relevant market on which it sells the contract goods or services, and the market share held by the buyer does not exceed $30 \%$ of the relevant market on which it purchases the contract goods or services.
} 

2017.

Final peer reviewed manuscript accepted in European Competition Journal,

330/2010, finally, lists a number of contractual restraints that are less suspicious than hardcore restrictions, but nonetheless worrying. If an agreement contains one of these restrictions, that particular restriction needs to be assessed individually under Article 101(3). However, the remainder of the agreement may still benefit from the block exemption.

It is the list of hardcore restrictions that has caused enforcers the greatest headache in the context of selective distribution agreements to date, and amongst these, Article 4(b)(iii) and (c) are of particular relevance for the issues under consideration.

Article (b)(iii) defines as a hardcore restriction:

the restriction of the territory into which, or of the customers to whom, a buyer party to the agreement, without prejudice to a restriction on its place of establishment, may sell the contract goods or services, except:

$(\cdots)$ the restriction of sales by the $m$ em bers of a selective distribution system to unauthorised distributors within the territory reserved by the supplier to operate that system.

In other words, combining a selective distribution system with an exclusive territory or customer allocation makes the agreement fall outside the scope of the block exemption. However, the manufacturer may prohibit the distributors from selling the contract good to third parties who are not part of the selective distribution network.

Article 4 (c) further defines as a hardcore restriction:

the restriction of active or passive sales to end users by members of a selective distribution system operating at the retail level of trade, without prejudice to the possibility operating out of an unauthorised place of establishment.

A selective distribution agreement in which the manufacturer imposes a restriction on the distributor's freedom to engage in active or passive sales therefore does not benefit from the block exemption contained in Regulation 330/2010. However, it is permissible to agree that the distributors only sell the contract goods from a place of establishment authorised by the manufacturer.

The key question that arises in the context of online sales is whether prohibiting members of a selective distribution system from selling the contract goods via the Internet amounts to a hardcore restriction within the meaning of Regulation 330/2010. The Court of Justice gave a partial answer to this question in Pierre Fabre. 

2017.

Final peer reviewed manuscript accepted in European Competition Journal,

\section{Pierre Fabre}

In Pierre Fabre, ${ }^{74}$ the investigated undertaking had argued that in view of its relatively low market share, it should benefit from the Block Exemption Regulation for Vertical Agreements in force at the time of the investigation, ${ }^{75}$ the predecessor of the current Regulation 330/2010. The wording of its list of hardcore restrictions was essentially the same as that of the current Regulation.

The Court of Justice took the view that a contractual clause prohibiting the Internet as a method of marketing had, at the very least, as its object the restriction of passive sales to end users wishing to purchase online and located outside the physical trading area of the relevant member of the selective distribution system. Scuh a clause therefore amounted to a hardcore restriction within the meaning of Article 4(c) of the Regulation. It was not persuaded by Pierre Fabre's argument that the ban on selling the contractual products via the Internet was a prohibition on operating out of an unauthorised establishment, but held that 'place of establishment' within the meaning of Article 4(c) referred to physical outlets and did not include the Internet. It did not explain its rationale for this finding beyond pointing out that there was no need to give an overly broad interpretation to 'place of establishment', because the non-applicability of the Block Exemption Regulation did not make an agreement automatically illegal and void. The restriction in question could still be assessed individually under Article 101(3) TFEU. Therefore, a contractual clause in a selective distribution agreement that prohibited the Internet as a method of marketing the contractual products had to be considered a hardcore restriction within the meaning of Article 4(c) of the Block Exemption Regulation on Vertical Restraints. ${ }^{76}$

\section{The remaining questions}

In Pierre Fabre, the Court took the view that the manufacturer had (de facto) imposed a blanket ban on selling Pierre Fabre products online. This was a very farreaching restriction, and the ruling made clear that the Court considers an absolute prohibition on the use of the Internet in the context of selective distribution a hardcore restriction which removes the benefit of the Block Exemption Regulation for Vertical Agreements entirely. What is the situation, however, if the manufacturer 'merely'

\footnotetext{
${ }^{74}$ Case C-439/09 Pierre Fabre, op. cit, para 46.

${ }^{75}$ Commission Regulation (EC) No 2790/1999 on the application of Article 81(3) of the Treaty to categories of vertical agreements and concerted practices [1999] OJ L336/21.

${ }^{76}$ Case C-439/09 Pierre Fabre, op. cit,, paras 55-59.
} 

2017.

Final peer reviewed manuscript accepted in European Competition Journal, prohibits his distributors from marketing the contract products via third-party auction platforms and virtual market places, such as amazon or ebay, while allowing them to sell the goods on their own websites? National courts are divided on the matter. While a few take the view that prohibiting appointed distributors within a selective distribution network should not be deemed a hardcore restriction, ${ }^{77}$ others have taken the opposite view since Pierre Fabre. ${ }^{78}$

Before proposing an answer to this question and the issues raised above on the interpretation of Article 101(1) TFEU, the following briefly explores the position of the European Commission.

\section{The European Commission's position}

The European Commission has not applied the Metro test in a while. However, the Commission's guidelines on vertical restraints ${ }^{79}$ spell out the Commission's understanding of the law and general approach to assessing vertical agreements under Article 101 TFEU and Regulation 330/2010. While these guidelines do not have the status of Union law and are not legally binding on anyone but the Commission itself, ${ }^{80}$ they are hugely influential in practice. They are an undertaking's first point of call when trying to establish how the main enforcement body interprets the law. Also, the national competition authorities and courts regularly rely on them for guidance when enforcing EU competition law. Occasionally, even the Court of Justice looks towards them for inspiration when interpreting the competition provisions, in particular for guidance on the underlying economic phenomena. ${ }^{81}$

The Commission's guidelines on vertical restraints do in fact not provide any guidance on whether the aim of protecting the luxury image of a product can ever justify the use of a selective distribution system in an assessment under Article 101(1) TFEU, and whether prohibiting distributors from marketing such goods on third-party platforms should be deemed a restriction of competition by object. However, they

\footnotetext{
${ }^{77}$ E.g. LG Mannheim, Judgment of 14 March 2008, Az 7 O 263/07; OLG Karlsruhe, Judgment of 25 November 2009, Az 6 U 47/08.

${ }^{78}$ E.g. KG Berlin, Judgment of 29 September 2013, Az. 2 U 8/09 (Kart); LG Frankfurt am Main, Judgment of 18 June 2014 - AZ. 2-03 O 158/13, para 37.

${ }^{79}$ European Commission, Guidelines on Vertical Restraints [2010] OJ C130/1.

${ }^{80}$ E.g. Cases C-23/14 Post Danmark A/S v Konkurrencerådet ECLI:EU:C:2015:651, para 52; C-226/11 Expedia EU:C:2012:795, paras 29 and 31.

81 E.g. Cases T-461/07 Visa Europe Ltd and Visa International Service $v$ Commission ECLI:EU:T:2011:181, para 170; T-321/05 AstraZeneca v Commission ECLI:EU:T:2010:266, para 88.
} 

2017.

Final peer reviewed manuscript accepted in European Competition Journal,

contain a number of relevant statements on when the Commission considers restricting the use of the Internet as a marketing tool a hardcore restriction within the meaning of Article 4(b) and (c) of Regulation 330/2010.

The guidelines are based on the premise that, in principle, every distributor, including members of a selective distribution network, should be allowed to use the Internet to sell products. ${ }^{82}$ However, they also make clear that the Commission considers certain restrictions on the use of the Internet compatible with the Block Exemption Regulation. In particular, the Commission considers it appropriate for the supplier to require quality standards for the use of the Internet site to resell his goods, just as he may require quality standards for a retail outlet, ${ }^{83}$ as long as they are overall equivalent to the criteria imposed for the sales from the brick and mortar shop ${ }^{84}$

The guidelines further state that the Commission considers it acceptable for the manufacturer to require that its distributors use third party platforms to distribute the contract products only in accordance with the standards and conditions agreed between the supplier and its distributors for the distributors' use of the Internet. In particular, where the distributor's website is hosted by a third-party platform, the supplier may require that customers not visit the distributor's website through a site carrying the name or logo of the third-party platform. ${ }^{85}$

In other words, the guidelines do not consider it a hardcore restriction within the meaning of Article 4(b) or (c) to prohibit the distributor from marketing goods on a third-party online platform that carries the name or logo of that third party. It has been argued in the literature that this interpretation of the Block Exemption Regulation is not compatible with the Court's interpretation of the Regulation 330/2010's predecessor in Pierre Fabre, and that the guidelines must be considered 'overruled' on this point. ${ }^{86}$ This was also the position, for example, of the German first instance court in Coty Germany, ${ }^{87}$ and it appears that the German competition authority takes the same view. ${ }^{88}$

\footnotetext{
${ }^{82}$ European Commission, Guidelines on Vertical Restraints, op. cit., paras 52, 56.

${ }^{83}$ Ibid, para 54.

${ }^{84}$ Ibid, para 54.

${ }^{85}$ Ibid, para 54.

${ }^{86}$ Knibbe, "Selective distribution and the ECJ's judgment in Pierre Fabre" [2012] 33 E.C.L.R. 450.

${ }^{87}$ LG Frankfurt a.M., Judgment of 31 July 2014, Az. 2-03 O 128/13 (Kart.).

${ }^{88}$ Bundeskartellamt, "Vertikale Beschränkungen in der Internetökonomie”, Working Paper of 10 October 2013, p. 24.
} 
2017.

Final peer reviewed manuscript accepted in European Competition Journal,

Analysis

The interpretation of Article 101(1) TFEU

Given that the Court continues to adhere to the Metro test ${ }^{89}$ for assessing the competitive impact of selective distribution agreements under Article 101(1) TFEU, the first question that needs to be addressed is whether preserving the 'luxury image' of a luxury good should be considered a legitimate aim within the meaning of the Metro case law. It is suggested here that the Court should rethink or at least rephrase its dictum in Pierre Fabre according to which the aim of maintaining a prestigious image can never be a legitimate aim for restricting competition. ${ }^{90}$ The Metro formula, reiterated in Pierre Fabre, is based on the premise that selective distribution can be compatible with Article 101(1) if the product in question necessitates such a network in order to preserve its quality or to ensure its proper use. ${ }^{91}$ Or, to use the langue of Pierre Fabre, the manufacturer must be pursuing a legitimate goal capable of improving competition in relation to factors other than price by means of its selective distribution system.

In the case of most luxury products, selective distribution is unlikely to be used to ensure their proper use. Most users of luxury cosmetics or clothing know how to use them. Selective distribution may be considered necessary in order to combat free-riding, and to ensure that distributors invest resources in customer service, which could be considered beneficial for consumers because it ensures the availability of this type of 'high frills' distribution channel, and could also be seen as enhancing interbrand competition. However, this is a separate issue. The problem under consideration here is whether preserving the 'luxury image' of a good should in principle be considered a legitimate purpose for using a selective distribution system.

There are good reasons to answer this question in the affirmative. The commercial value of a luxury good is not only determined by the material quality of its components or the craftsmanship that has gone into making it. There is also a psychological component to its value. Consumers value items belonging to successful luxury brands partially or even primarily because of the image associated with this

\footnotetext{
${ }^{89}$ Case 26/76 Metro SB-Großmärkte v Commission ('Metro I') ECLI:EU:C:1977:167; Case 75/84 Metro SB-Großmärkte v Commission ('Metro II') ECLI:EU:C:1986:399.

${ }^{90}$ C-439/09 Pierre Fabre, op. cit., para 46.

${ }^{91}$ Cases 26/76 Metro I, op. cit., para 20; 107/82 AEG-Telefunken v Commission ECLI:EU:C:1983:293, para 35; 31/80 L'Oréal ECLI:EU:C:1980:289, para 15; C-439/09 Pierre Fabre, op. cit., para 41.
} 

2017.

Final peer reviewed manuscript accepted in European Competition Journal,

brand. A handbag made by a luxury brand is not necessarily better made, or of higher quality materials, than that of a less prestigious brand. Nonetheless, certain consumers are willing to pay a higher price for the luxury item because of the brand image. Understanding why certain consumers value luxury and what makes them consider something a luxury good in the first place is the subject of research across many disciplines. Whatever the exact psychological mechanism may be, there is widespread agreement amongst economists, psychologists and marketing experts that the image and perception of exclusivity in the eyes of consumers is a key characteristic and component of the good. ${ }^{92}$

The Court of Justice of the European Union itself recognised this phenomenon in a number of judgements. For example, this was the position of the General Court in the case of Edouard Leclerc discussed above, where it held that the characteristic of a luxury good could not be limited to its material characteristics, but that it also encompassed the specific perception that consumers had of it, in particular its 'aura of luxury'. ${ }^{93}$ While it has been suggested that the Court of Justice overruled this principle in Pierre Fabre, ${ }^{94}$ it is curious that it should have done so without even mentioning the ruling in Edouard Leclerc. Moreover, in the area of EU trademark law, the Court has repeatedly held that the quality of luxury goods is not just the result of their material characteristics, but also of their "allure and prestigious image" in the eyes of consumers, which bestows upon them an aura of luxury. In Copad v Christian Dior, for example, the Court therefore concluded that an impairment to that aura of luxury was likely to affect the actual quality of those goods. On that basis, it held that the proprietor of a trade mark could invoke the rights conferred by that trade mark against a licensee who contravened a provision in a licence agreement prohibiting, on grounds of the trade mark's prestige, sales to discount stores, provided that it had been established that that

\footnotetext{
92 See e.g. Weidmann, Hennings and Siebels, "Value-based segmentation of luxury consumption behavior” (2009) 26 Psychology \& Marketing 625; Vigneron and Johnson, “A review and a conceptual framework of prestige-seeking consumer behaviour” (1999) 1 Academy of Marketing Science Review 1; Berry, The Idea of Luxury: A Conceptual and Historical Investigation (CUP 1994); Kemp, "Perceiving luxury and necessity" (1998) 19 Journal of Economic Psychology 591; Hansen and Wänke, "The abstractness of luxury” (2011) 32 Journal of Economic Psychology 789; Pruzhansky, "Luxury goods, vertical restraints and internet sales" (2014) 38 European Journal of Law and Economics 227; Brun and Castelli, "The nature of luxury: a consumer perspective" (2013) 41 International Journal of Retail \& Distribution Management 823.

${ }^{93}$ Case T-19/92 Groupement d'achat Edouard Leclerc, op. cit., paras 113-115.

${ }^{94}$ Knibbe, "Selective distribution and the ECJ's judgment in Pierre Fabre” [2012] 33 E.C.L.R. 450.
} 

2017.

Final peer reviewed manuscript accepted in European Competition Journal, contravention damaged the allure and prestigious image which bestowed on those goods an aura of luxury. ${ }^{95}$

If one thus accepts that, in the case of luxury goods at least, the image of exclusivity is an integral part of the good, one also has to accept that if the image is tarnished, the good loses in value. This is not only detrimental to the producer, but also to those consumers who appreciate such goods. Therefore, the protection of a luxury image should, in principle, be considered a legitimate goal for operating selective distribution networks under Article 101(1) TFEU. Any other position would result in reducing consumer welfare by depriving consumers of a type of product they value, even if this appreciation may be considered irrational or even morally questionable by others. However, these other consumers need not purchase such goods. As long as there is sufficient inter-brand competition and a sufficient number of alternatives in the form of non-branded products, or products of a less prestigious brand that compete primarily on the basis of material quality and price, the welfare of those consumers who do not value luxury goods is not affected. Ultimately, not allowing manufacturers of luxury goods to protect the exclusive image of their products at all by means of vertical restraints is likely to make them stop using independent retailers and revert entirely to vertically integrated sales outlets, which is not in the interest of competition or consumers.

This does not mean, of course, that competitive restraints imposed by a manufacturer to protect the luxury image of his goods are off limits for competition authorities. The Metro test imposes several further conditions in addition to the legitimate aim. In particular, it requires that the restraints be necessary to achieve the legitimate aim. This raises the question whether a ban on the use of third-party platforms is really necessary to protect the aura of exclusivity of a luxury good.

Producers of luxury goods commonly argue in judicial proceedings that marketing luxury goods on general auction platforms such as ebay, for example, which has been likened to the virtual equivalent of a real world flea market, has a negative

\footnotetext{
${ }^{95}$ Case C-59/08 Copad v Christian Dior couture et al ECLI:EU:C:2009:260, para 24; Likewise: Case C337/95 Parfums Christian Dior v Evora ECLI:EU:C:1997:517, para 45. Similarly, Case C-324/09 L'Oréal and Others v eBay International and Others ECLI:EU:C:2011:474, para 78.
} 


\section{7.}

Final peer reviewed manuscript accepted in European Competition Journal,

effect on these products' image of exclusivity. ${ }^{96}$ This does not seem implausible, and the same may be true for virtual market places such as amazon. It is the manufacturer who bears the burden of proving such an effect in the individual case. However, it seems that a blanket ban on the use of third-party platforms, at least, would go beyond what is necessary to protect these good's image. There are third-party platforms that specialise in the distribution of luxury goods. Should they meet the criteria required by the manufacturer for the authorised distributor's own online shop, it is not immediately obvious why the image of goods should suffer more on such a platform than from the sale through the distributor's online site. A less restrictive restraint than a blanket ban would therefore be to make the distribution via third-party platforms conditional on the manufacturer approving the third-party platform on the basis of the same objective, qualitative and proportionate criteria it requires from the distributor's online shop. Assessing whether the qualitative criteria imposed on distributors and third-party platforms are necessary is not straightforward, and different enforcement bodies are bound to reach different conclusions. This, however, is a general weakness of the Metro formula and its proportionality test, rather than a problem that is specific to the marketing of luxury items.

Incidentally, a case could be made that the legitimacy of protecting a brand name and image should not be limited to luxury brands only, but be extended to any brand. The Court's case law on franchising is based on the very premise that the franchisor has a legitimate interest in protecting his brand, and therefore considers that contractual restraints that are necessary for maintaining the identity and reputation of the network bearing the franchisor's business name or symbol do not amount to restrictions of competition within the meaning of Article 101(1) TFEU. ${ }^{97}$ Again, this would not mean that the manufacturer were given carte blanche for protecting the reputation of his brand with unreasonable criteria. Under the Metro formula, restrictions of competition in pursuit of the legitimate aim are only compatible with Article 101(1) TFEU if they are proportionate. The focus of the assessment would therefore be whether the brand image really was in danger in the individual case and, if so, whether the restrictions in question were necessary to address this danger.

\footnotetext{
${ }^{96}$ E.g. LG Frankfurt a.M., Judgment of 31 July 2014 Az. 2-03 O 128/13 (Kart). See also: Caffarra and Kühn, "Selective Distribution of Luxury Goods in the Age of E-commerce", An Economic Report for Chanel (2008).

${ }^{97}$ Case 161/84 Pronuptia de Paris, op. cit., para 17.
} 

2017.

Final peer reviewed manuscript accepted in European Competition Journal,

The interpretation of Article 4 (b) and (c) of Regulation 330/2010

This leaves the question whether a blanket ban on the use of third-party platforms amounts to a hardcore restriction within the meaning of Article 4(b) or (c) or Regulation 330/2010,

Article 4(b) of Regulation 330/2010 prohibits manufacturers from restricting the territory into which the distributor may sell as well as a restriction of the customers to whom the distributor may sell, although mere restrictions on the distributor's place of establishment and restricting sales by the members of a selective distribution system to unauthorised distributors do not qualify as hardcore restrictions within the meaning of Article 4(b). Article 4(b) therefore aims to prevent the combination of selective distribution with exclusive distribution. Prohibiting the use of third-party online platforms does not amount to either territorial allocation or customer allocation. It is a restriction of the means by which the distributor may sell, not an exclusivity clause that protects another distributor, and should therefore not be considered a hardcore restriction within the meaning of Article 4(b).

However, in view of the Court's ruling in Pierre Fabre, it could amount to a hardcore restriction within the meaning of Article 4(c) of Regulation 330/2010. Article 4(c) prohibits the restriction of active or passive sales to end users by members of a selective distribution system at the retail level, without prejudice to the possibility of prohibiting a member of the system from operating out of an unauthorised place of establishment. In Pierre Fabre, the Court of Justice held that prohibiting the use of the Internet as a method of marketing at the very least had as its object the restriction of passive sales to end users wishing to purchase online and located outside the physical trading area of the relevant member of the selective distribution system. ${ }^{98}$

This is a very broad understanding of what constitutes a restriction of passive sales. The concepts of active and passive sales were coined at a time where the Internet did not exist as a method of communication, and they do not translate very easily to ecommerce. They were originally developed for the assessment of exclusive distribution agreements, in which the manufacturer allocated exclusive territories or customers to specific distributors. Essentially, a restriction of passive sales referred to a prohibition imposed on a distributor to sell into another distributor's exclusive territory (or to

\footnotetext{
${ }^{98}$ Case C-439/09 Pierre Fabre, op. cit., para 54.
} 

2017.

Final peer reviewed manuscript accepted in European Competition Journal, another distributor's exclusive customers) even if he had been approached by a customer allocated to the other distributor. An agreement to restrict active sales amounted to prohibiting distributors from actively approaching customers allocated to another distributor (either personally or by territory) to initiate a sale. ${ }^{99}$ In the context of pure exclusive distribution agreements, only a restriction of passive sales is deemed so serious that it is considered a hardcore restriction within the meaning of the Block Exemption Regulation ${ }^{100}$ as well as a restriction by object within the meaning of Article 101(1) TFEU. In the context of selective distribution agreements, Article 4(c) of the Block Exemption Regulation also considers a restriction of active sales a hardcore restriction. The concepts are remnants of the original freedom-based understanding of anticompetitive effects under EU competition law ${ }^{101}$ rather than the current welfarebased interpretation nowadays favoured by the European Commission.

Likening a restriction on the distributor's freedom to respond to actual sales requests, the classical definition of passive sales, to one in which a distributor is not allowed to sell his goods via the Internet to hypothetical customers is quite a stretch. In the case of Pierre Fabre, the distributors were not actually prohibited from responding to sales requests. The prohibition of selling online merely diminished the possibility that customers would make such a request because it eliminated one channel of communication. It is not a restriction of the right to engage in active sales either, in the strict sense of the term. Pierre Fabre's distributors were allowed to target customers anywhere by means of advertising. However, the prohibition to sell via one's own online shop could be seen as diminishing the distributor's chances of making active sales to consumers situated outside his physical trading area.

Regardless of whether one qualifies a blanket ban on the use of the Internet as a sales method as a restriction of active or passive sales, the concept has been extended from one that originally referred to a complete prohibition on selling to one that includes measures that hypothetically diminish the likelihood of selling. If one now extended the concept to the restriction on the use of specific types of online marketing methods, it would become even broader. Where does one draw the line? Should any contractual clause that affects a distributor's ability to sell the contract goods be

\footnotetext{
99 See e.g. European Commission, Guidelines on Vertical Restraints, op. cit., para 51.

100 Article 4(b)(ii) of Regulation 330/2010.

${ }^{101}$ See Witt, The More Economic Approach to EU Antitrust Law (Hart Publishing, 2016), Chapter 5.
} 

2017.

Final peer reviewed manuscript accepted in European Competition Journal, considered a restriction of active or passive sales? Hardcore restrictions within the meaning of a Block Exemption Regulation are the equivalent of restrictions by object within the meaning of Article 101(1) TFEU. Only the most obvious and serious restrictions should be caught by them because of the legal presumptions that they trigger. While the Court of Justice held in Pierre Fabre that there was no need to interpret Article 4(c) overly restrictively because agreements that were caught by the provision could still be assessed individually under Article 101(1) TFEU, ${ }^{102}$ there is also good reason not to interpret the hardcore restrictions too broadly either, as this would runb counter the very purpose of the Block Exemption Regulation, which is to avoid costly and uncertain individual assessments.

The key difference between the case of Pierre Fabre and a 'mere' restriction on the use of third-party platforms is that, in the latter case, distributors are allowed to sell the relevant goods through their own online shops, and thus reach consumers outside their physical trading area. There may be circumstances in which using a third-party platform may be more advantageous to a distributor than setting up and operating his own online shop. However, if one takes into account the aim of protecting competition, the competing principle of contractual autonomy, the great efficiency potential of vertical agreements and the recognised fact that vertical agreements between undertakings with a relatively low market share are unlikely to result in serious anticompetitive effects, this possibility should only warrant qualifying a prohibition on the use of third-party platforms as a hardcore restriction if there were empirical evidence to suggest that banning the use of third-part platforms de facto amounted to banning the use of the Internet as a sales method. On this basis, it is suggested that, in the absence of such evidence, a contractual prohibition on the use of third-party platforms should not be considered a hardcore restriction under Article 4(c).

If one nonetheless took the view that a prohibition on the use of third-party online platforms, while allowing online sales via the distributor's own website, amounted to a restriction of sales worthy of a hardcore restriction, one would need to ask oneself whether the prohibition to use third-part platforms should not be likened to a prohibition on selling out of an unauthorised place of establishment after all, which Article 4(c) of Regulation 330/2010 explicitly permits. In Pierre Fabre, the Court held

\footnotetext{
${ }^{102}$ Ibid, para 57. To be exact, the Court held that it was not necessary to interpret the exception contained in Article 4(c) too broadly.
} 

2017.

Final peer reviewed manuscript accepted in European Competition Journal, that 'place of establishment' within the meaning of Article 4(c) of former Regulation 2790/1999, the predecessor of the current Block Exemption Regulation on vertical restraints, referred to outlets where direct sales take place and not the Internet. ${ }^{103}$ The Court justified this position with the argument that there was no need to adopt a broad interpretation of the concept because undertakings had the option to assert, on an individual basis, the applicability of the exception provided for in Article 101(3) TFEU. ${ }^{104}$ Should the Court in future take the view, however, that restricting the use of third-party platforms does amount to a restriction of sales within the meaning of Article 4(c) of Regulation 330/2010, it would be worth reconsidering this position, especially in view of the fact that Article 101(3) TFEU defences tend not to succeed these days. Further, the exception contained in Article 4(c) reflects the Court's own previous rulings according to which the manufacturer is allowed to select distributors on the basis of objective criteria of a qualitative nature relating to the technical qualifications of the reseller and the suitability of his trading premises, laid down uniformly for all potential resellers and not applied in a discriminatory fashion. ${ }^{105}$ If this type of restriction does not even amount to a restriction of competition within the meaning of Article 101(1) TFEU, it would be nonsensical to consider it a hardcore restriction within the meaning of Regulation 330/2010. Why differentiate between physical and virtual sales places? Third-party platforms can be likened to virtual marketplaces or auction houses, depending on their modi operandi. Their design and business policies are just as likely to influence consumer's shopping experience as those operated in a brick and mortar outlet. If, however, it is compatible with EU competition law to prohibit an authorised distributor from selling from an unauthorised physical market stall, why should it be more objectionable for the manufacturer to prohibit him from selling on an unauthorised virtual marketplace? The situations seem comparable. Again, this does not mean that a blanket prohibition on the use of third-party platforms should be considered proportionate within the meaning of Article 101(1) TFEU. However, it does not seem logical to consider banning the use of unauthorised third-party virtual platforms a hardcore restriction within the meaning of Regulation 330/2010 if one does not take the same view with regard to brick and mortar outlets.

\footnotetext{
${ }^{103}$ Case C-439/09 Pierre Fabre, op. cit., para 56.

${ }^{104} \mathrm{Ibid}$, paras 57, 58.

${ }^{105} \mathrm{Ibid}$, para 20.
} 
Final peer reviewed manuscript accepted in European Competition Journal, 2017.

\section{Conclusion}

In sum, it is suggested that the Court should reconsider, or at least rephrase, its ruling in Pierre Fabre that the protection of a brand's prestigious image is not a legitimate aim capable of justifying a restriction of competition under Article 101 TFEU. At least in the context of so-called luxury products, it is in the interest of consumers that the image of exclusivity be protected. They should therefore be seen as necessitating selective distribution under the Court's Metro case law. A blanket ban on selling via third-party platforms, however, seems disproportionate, as a less restrictive means of protecting the brand image would be to make the use of third-party platforms conditional on approval by the manufacturer, on the basis of the same qualitative criteria as those required of distributors' own online shops. By contrast, it is argued that it would be counterproductive to consider a ban on the use of third-party platforms, while allowing other forms of online sales, a hardcore restriction within the meaning of Article 4 of Regulation 330/2010. Ultimately, whatever position the Court of Justice eventually decides to adopt, it is imperative that it provide clear and workable answers for the national enforcement bodies at the next opportunity in order to restore the uniformity of EU law on this point. Hopefully the preliminary ruling in the case of Coty Germany ${ }^{106}$ will do exactly this.

\footnotetext{
${ }^{106}$ Request for a preliminary ruling from the Oberlandesgericht Frankfurt am Main (Germany) lodged on 25 April 2016 - Coty Germany GmbH v Parfümerie Akzente GmbH (Case C-230/16) [2016] OJ C260/21.
} 